\title{
THE PROGRAM “PHILOSOPHY FOR CHILDREN”: POSITIVE EXPERIENCE OF THE USA
}

\author{
Yulia Zahrebniuk \\ Pavlo Tychyna Uman State Pedagogical University, Ukraine \\ Liudmyla Veremiuk \\ Pavlo Tychyna Uman State Pedagogical University, Ukraine \\ Ilona Boichevska \\ Pavlo Tychyna Uman State Pedagogical University, Ukraine \\ Anna Ivanchuk \\ Pavlo Tychyna Uman State Pedagogical University, Ukraine
}

\begin{abstract}
The article deals with the peculiarities of theprogram "Philosophy for children" and possibility of its introduction at both junior schools and the lyceums in Ukraine. The aim of the article is to show the positive attitude of American educators to the program. The results of the research show that logical reasoning and intellectual creativity are not mutually exclusive, and can be formed within a single program. The authors claim that "Philosophy for children" program is undoubtedly relevant and needs not only active development but also promotion and dissemination among representatives of the academic philosophical community, educators, representatives of the relevant institutions of state power and general public.
\end{abstract}

Keywords: critical thinking, curriculum, education, philosophy, positive experience, program, skills.

\section{Introduction}

Reforming the national education system leads to a change of the technocratic paradigm of education and young generation upbringing to a humanistic, person oriented. Such a system should prepare the person for process of adaptation to life in a world characterized by dynamism, work intellectualization, rapid technology flow, a large number and variety of contacts. According to the philosophy of New European time (Abbasi, Pirani, Sarmadi, Taghvaee, 2017; Chetty \& Suissa, 2017; Gregory, Haynes, Murris, 2017; Haynes, Murris, 2017; Gregory, Laverty, 2018 \& Michalik, 2018) a person is a conscious being, capable of accepting himself, thinking critically, analyzing and adjusting behavior according to life circumstances.Therefore, modern Ukrainian pedagogical science and school practice are in search of a 
Zahrebniuk et al., 2021. The Program "Philosophy for Children":

Positive Experience of the USA

new educational strategy, which would be directed to the development of essential forces of the child's personality.

Orientation towards the development of students' thinking, the formation of moral and reflexive behavior in them, make it urgent to search for a means of effective solution of these problems. Considerable theoretical and practical capacity can be found in the scientific works of American scientists who under M. Lipman's leadership (Lipman, Sharp, \& Oscanyan, 1980) developed the program "Philosophy for Children" for school-aged children. Its content and technology are aimed at teaching children philosophy, engaging into which helps them to develop critical thinking skills and tolerant behavior.

Looking into the history of development we might admit that the course "Philosophy for Children" was created over a long period of time (the first development dates from the early 70's of the $20^{\text {th }}$ century) with the active participation of teachers and child psychologists.

The result was the development and justification of its conceptual foundations, the development of significant scientific and methodological support, which includes theoretical works, didactic manuals for teachers, texts for children translated into 40 languages. However, work in this area does not stop. The content and technology of the course implementation are open for discussion, which creates prerequisites for engaging pedagogical public to identify existing problems and make suggestions, discussions and experience exchange take place. It confirms the viability of the approaches formulated by M. Lipman and his colleagues (Lipman, Sharp, \& Oskanyan, 1979) their practical feasibility.

The aim of our research is to show the attitude of American educators to the program "Philosophy for children" (Shirman, 1982; Trickey, Topping, 2004; Bleazby, 2013; Reed-Sandoval, 2018; Pritchard, 2018; Siegmund, 2019; Siegmund, 2020; Murris \& Haynes, 2020) to analyze the development of this program and to characterize the possibilities of its implementation in the Ukrainian school system.

\section{Literature Review and Methodology}

The theoretical foundations of the Philosophy for Children course are the natural inclinations of students which are used during the process of its implementation. Taking into account the ideas of J.Piaget and L.Vygotsky (Piaget, 1933; Vygotsky, 1997) and practical experience, the developers pay particular attention to the fact that philosophical lessons should by no means be an artificial innovation. According to M. Lipman, they "must rely on such human qualities as curiosity, wonder, the need to learn the world in a playing method and enjoy the game. In other words, philosophy can be for the intellect 
the same thing as a sports game is for the development of the musculoskeletal system” (Lipman, Sharp, \& Oskanyan, 1979, p. 8).

The program of Philosophy for Children is aimed at teaching children to philosophize, not philosophy itself. That is, philosophy here is not a matter of study, but a means of reflecting the world and attitude to it. Establishing a close connection of philosophy with practice is different from the traditional paradigm of learning: the focus is not on remembering information (memory work), but on active "creation" of philosophy that requires effort from the intellect and solution of problems related to students' real life (Lipman, Sharp, Oskanyan, 1979, p. 20). These issues are of particular importance for young school-aged children, when major mental processes and personality traits are formed, such as arbitrariness, an internal plan of actions and reflection, which enable the child to regulate his or her activity and behavior at a "certain level of independence, taking into account the peculiarities of the activity itself" (Masharova \& Khodyreva, 1998).

Doing philosophy helps the child move from the superficial level of things to their deep, essential level. J. Dewey wrote: "There is no phase in the development of education, economy, politics or religion where critical thinking does not help to come into the world because, according to Matthew Arnold, it was not born yet” (Dewey, 1967, p.18).

The course developers are aware that philosophy promotes selfimprovement when it is the result of students' practical work. Engaging in philosophy, they learn to have an open discussion, following the appropriate rules of behaviour and communication. To do philosophy together is "not only a way to criticize such foundations of our culture as inherited ideas and values that stand on the way to freedom. It is also a way of creative updating the old and generating new life prospects. It is a way to teach yourself to think by yourself, to think in a new way, to enrich each other's experience, to enable your child to identify their problems and to make qualitative hypotheses about their successful solution” (Yanovs'kyy, 2001, p. 20; Kizel, 2016).

Since its introduction, the program Philosophy for Children has been evaluated in various schools in the United States. The first evaluation, held at Randall School, Montclair (New Jersey) dates back to 1970. The next evaluation of the program was conducted by Hope Hoan in 1975 in New York. In 1976, a large-scale program review was conducted by Virginia Shipman in New YorkPrompton Lakes (Shipman, 1983). The main purpose of this examination was to answer the question if the work of the students under the program Philosophy for Children is successful according to such parameters as: 1) reasonable thinking; 2) speed in the formation and perception of ideas; 3) academic training; 4) reading and math. The following test was used to evaluate the results: 
Zahrebniuk et al., 2021. The Program "Philosophy for Children":

Positive Experience of the USA

Skills type:

1. Reasonable thinking (Methods: A test framework for evaluating formal reasoning, developed by the Educational Testing Service and known as Q-3. Intellectual Output Test taken from the California Intellectual Test).

2. Arguments with alternatives and opportunities (Methods: The test "What could it be?"; The test "How can this be used?"; The test "How many reasons are there for it?”).

3. Productivity in the formation and perception of ideas (Methods: The test "What could it be?"; The test "How can this be used?"; The test "How many reasons are there for it?").

4. General training (Methods: Student's diary).

5. Success in reading and math(Methods: "Metropolitan" Prompton Lakes Success Test: California Core Skills Test) (Childhood and Philosophy Special Issue [CPSI], 2017).

\section{Research Results}

Obtained data showed the significant success of students in various fields. In addition, the results show that logical reasoning and intellectual creativity are not mutually exclusive and can be formed within a single program (Shirman, 1982). Another reason for the positive attitude of many American educators to the program Philosophy for Children is its authors' dedication to critical thinking. As one of Montclair University professor M.Weinstein points out, "only in the case of critical thinking practice genuine learning, affirmation of democracy, alleviation of contradictions based on the details of certain contexts can be found" (Vaynshteyn, 2001, p. 50).

Critical thinking is not considered as one of additional aspects of the curriculum at school, but as something that is deeply integrated into the very essence of the whole system of learning. Let's take a look at the basic thinking skills offered by the program Philosophy for Children (The skills were identified in the result of the large-scale inspection conducted by Virginia Shipman in New-York-Prompton Lakes in 1976) (Table 1).

Table 1 Thinking Skills that M. Lipman's Program Philosophy for Children is Directed to (Lipman, 1980, Lipman, 1988, Lipman, 1991, Lipman, 2003, Lipman, Sharp, Oscanyan, 1980)

\begin{tabular}{|c|c|}
\hline \multicolumn{2}{|c|}{ Skill 1. Accurate formulation of concepts } \\
\hline Description & Examples \\
\hline $\begin{array}{l}\text { When applying a concept to a particular set } \\
\text { of cases, children should be able to determine }\end{array}$ & $\begin{array}{l}\text { Discussion plan for exploring the concept of } \\
\text { "friendship": }\end{array}$ \\
\hline
\end{tabular}


whether these cases really fall within the scope of the concept, and to find those that are beyond it.They should be encouraged to provide counter-examples when they believe that the boundaries of the concept are not well defined. Discussion exercises and plans focus on boundary cases.

\section{Skill 2. The ability to make appropriate generalizations}

A set of facts is given. The student should be able to highlight the similarities and regularities and make some generalizations that are appropriate for all of these facts and similar ones. In addition, the student should be aware of the dangers contained in these generalizations.

\section{Skill 3. Formulation of cause and effect relationships}

Students should be able to identify and give verbal formulations which relate to specific cause and effect relationships. In addition, they should be able to find examples of errors such as "After this - therefore, as a result".

1. I always blink my eyes when I see a mouse, and I only blink my eyes when I see a mouse, should I assume that the reason for the blinking is that I see the mouse?

2. In which part of the sentence is the reason given, and in which - the consequence? "The rivers were spilled because there were heavy rains”.

\section{Skill 4. The ability to draw direct conclusions from a single link}

Students should be able to perform logical generalizations andto know the rule of true and false treatment. In addition, they should be aware of and able to construct exceptions to this rule, such as identical statements.

\section{Skill 5. The ability to draw syllogistic conclusions from two references}

Students should be able to draw correct conclusions from true syllogisms and identify at least some examples of false conclusions.

1. "All dogs are animals, all collies are dogs, therefore, all collies are animals".

2. "But if you put the word 'fish' at the end of
1. If a true statement begins with the word "none", then its appeal will be true, and if it begins with the word "all”, then its appeal is false.

2. Add a word that will make this statement identical: "All adults ..." the first two statements, the word would seem to cross everything, and your conclusion would be wrong".

\section{Skill 6. Knowledge of basic rules of standardization}

Students should be familiar with the basic rules of standardization and be able to apply them.
1. Include the following statements to the sentences that contain the word "all": "Every American is a patriot", "Americans are patriots", "Any American is a patriot".

2.The following words shall be added to the 
Zahrebniuk et al., 2021. The Program "Philosophy for Children":

Positive Experience of the USA

\begin{tabular}{|l|l|}
\hline & $\begin{array}{l}\text { sentences containing the word "none": } \\
\text { "Submarines are never airplanes", "No } \\
\text { submarine is an airplane”. } \\
\text { 3. In sentences beginning with "some", the } \\
\text { subject and predicate are rearranged, after } \\
\text { which they can be considered as sentences } \\
\text { beginning with "all”. }\end{array}$ \\
\hline
\end{tabular}

Skill 7. Knowledge of the rules regarding ordinary logic and logic of relations

Students should be aware of the rules 1 . If Sue is sadder than Sally, then Sally governing transitive and symmetric cannot be sadder than Sue. But if Lola can relationships. They also need to know the not stand guys, it does not mean guys can not standardization rule that allows you to stand Lola.

convert nontransitive relationships into 2 . If oilfuel is more viscous than oil and oil is transitive ones. more viscous than water, oil fuel is more viscous than water.

3. The following statement is given: France is more than England. France is smaller than Canada. Flip the ratio to one of these sentences to make the transition possible (e.g., Canada is larger than France).

Skill 8. Determination of logical consistency and contradiction

Students should recognize consistency or empathy in a given set. In addition, they must be able to formulate and apply formal rules of contradiction.
1. If I really care about animals, I will never eat them.

2. If two sentences are mutually contradictory, and one of them is true, then the other will be false. Example: "Some matches that burn, do not curl up"contradicts the statement "All matches that burn, curl up".

Skill 9. The ability to draw conclusions from conditional syllogisms in propositional logic Students should be able to distinguish In hypothetical deduction, it is possible to between right and wrong conclusions when working with hypothetical syllogisms (If... then...).

\section{Skill 10. Question formulation} assert an antecedent or to deny the consequent. It is inadmissible to reject the antecedent or the denial of the consequent. For example, let's say, with the truth of the links: If I click on this button, it will burst. It did not explode. Apparently, I did not press the button - (denial of the consequent).

Students should be aware of the errors in the question and be able to formulate the questions in order to avoid the difficulties.

\section{Skill 11. The ability to identify the links that underlie the utterances}

A true statement is given, the student should 1. Lisa supposes that the truth or falsity of a be able to find the links that underlie it and
Questions may be based on incorrect assumptions, they may be vague, overloaded, internally contradictory or, simply, meaningless. E.g.: how many digits are there in the largest number? statement depends on what we accept as a 


\begin{tabular}{|c|c|}
\hline $\begin{array}{l}\text { determine which links are true statements } \\
\text { accidental. }\end{array}$ & $\begin{array}{l}\text { reference. If something contradicts ourviews, } \\
\text { and they are true, they may be false. } \\
\text { 2. Find the assumptions that are the main: "I } \\
\text { like your hair. Which hairdresser did you go } \\
\text { to? " }\end{array}$ \\
\hline \multicolumn{2}{|c|}{ Skill 12. Understanding “part-whole”, “whole-part” relationships } \\
\hline $\begin{array}{l}\text { Students must learn to avoid errors related to } \\
\text { the problem of the whole and the part of } \\
\text { thewhole, that is, the judgment that if an } \\
\text { element has a feature, then it is inherent in } \\
\text { the whole group of elements. It is also } \\
\text { important to avoid the opposite nature when } \\
\text { attributing the whole or group to the } \\
\text { constituent elements. Pupils should be well } \\
\text { aware of the double content of expression } \\
\text { "being part of something". }\end{array}$ & $\begin{array}{l}\text { 1. Misunderstanding of the "part-whole" } \\
\text { attitude: "If Michael has good facial features, } \\
\text { then he must have a handsome face". } \\
\text { 2. Misunderstanding of the whole-part } \\
\text { relationship: "If Marry has a pretty face, then } \\
\text { she must have good features". } \\
\text { 3. If Hawaii is part of the United States and } \\
\text { the United States is part of North America, } \\
\text { then is Hawaii part of North America? }\end{array}$ \\
\hline \multicolumn{2}{|c|}{ Skill 13. Understanding when to avoid, when to allow and when to use ambiguity } \\
\hline $\begin{array}{l}\text { It is necessary to be able to find and avoid } \\
\text { ambiguities in information that is logically } \\
\text { analyzed, since in this case they are too } \\
\text { harmful. In the social sphere, ambiguities can } \\
\text { sometimes be tolerated, because quite often } \\
\text { they cannot or should not be excluded. In } \\
\text { poetry ambiguities are very valuable, they } \\
\text { enrich the idea. Students should be able to } \\
\text { distinguish between the ambiguities that } \\
\text { result from the originality of some words and } \\
\text { the ambiguities that result from the particular } \\
\text { arrangement of words (i.e, semantic and } \\
\text { syntactic ambiguities). }\end{array}$ & $\begin{array}{l}\text { 1. Harry does not know if Bill regretted } \\
\text { throwing a stone at him. Bill's behavior is } \\
\text { ambiguous. But, after all, Harry invites Bill to } \\
\text { play the 'freeze-melt'. } \\
\text { 2. "Has somebody almost touched you?" - } \\
\text { What is meant here - physical touch or some } \\
\text { interest? There may be different content here. }\end{array}$ \\
\hline \multicolumn{2}{|c|}{ Skill 14. The ability to recognize incomprehensible words } \\
\hline $\begin{array}{l}\text { Misunderstood words have no clear } \\
\text { application limits. Students should recognize } \\
\text { such words and distinguish between contexts } \\
\text { in which such words are acceptable and those } \\
\text { in which they are inappropriate. }\end{array}$ & $\begin{array}{l}\text { 1. "At what exactly temperature does the } \\
\text { water become warm?" } \\
\text { 2. "Can a society be democratic and not have } \\
\text { a representative system of government?" } \\
\text { 3. "Can a multi-party society be } \\
\text { undemocratic?" }\end{array}$ \\
\hline
\end{tabular}

In the proposed technology by American researchers (Lipman, Sharp, Oscanyan, 1980; Lipman, 1980; Lipman, 1988; Lipman, 1991, \& Lipman, 2003) the application of philosophy for children, the main thing is philosophizing on the material of philosophically enriched stories. Almost all of them are named after the protagonists, making it possible to personalize the philosophical problems, are inherent in the content and make them accessible to primary schoolchildren. 
Zahrebniuk et al., 2021. The Program "Philosophy for Children":

Positive Experience of the USA

Anotherblock technology of "Philosophy for Children"is about changing the content and form of the lesson, transforming it into a "Socratic method". This is achieved through the creation of a community of researchers, based on a dialogue, engaging in which students learn to ask questions, criticize weak reasoning, build reasoned judgments, take responsibility for their contribution to the overall context of the debate, be aware of others, depend on others, respect their views, jointly engage in self-correction, master the skills of making good judgments.

"Philosophy for Children"is aimed at helping children to actualize their intellectual and spiritual capacity, which forvarious reasons, may be suppressed or left unused because of limited education; development of cognitive skills, critical and creative thinking. The critical thinking skills that are the subject of the program "Philosophy for Children" are described in the following table:

\section{Table 2 The Formation of Critical Skills within the Program Philosophy for Children}

(Lipman, 1973, p.93)

\begin{tabular}{|c|c|c|}
\hline General philosophical skills & $\begin{array}{l}\text { Open thinking (cooperation } \\
\text { relations, ability to take into } \\
\text { account the opinion of others) }\end{array}$ & $\begin{array}{l}\text { Logic (analysis and synthesis } \\
\text { skills): }\end{array}$ \\
\hline $\begin{array}{l}\text { The ability to: } \\
\text { - ask questions related to } \\
\text { discussion issues; } \\
\text { - not to resort to stereotypes in } \\
\text { statements; } \\
\text { - skills to make arguments (to } \\
\text { avoid unverified judgments } \\
\text { and statements like } \\
\text { "Everybody doesit"); } \\
\text { - hypothesis (prediction) skills; } \\
\text { - hypothesis testing skills } \\
\text { (check if it will work in } \\
\text { different situations); } \\
\text { - add-on skills (develop not } \\
\text { only your own predictions, but } \\
\text { also others). }\end{array}$ & $\begin{array}{l}\text { Implies the desire to: } \\
\text { - accept reasonable criticism } \\
\text { (to avoid situations of "deaf } \\
\text { protection", not to defend } \\
\text { opinion only in order to } \\
\text { achieve this); } \\
\text { - not to be a slave of a single } \\
\text { conviction (not to rush to } \\
\text { accept any argument as the } \\
\text { only correct one); } \\
\text { - respect others and their rights } \\
\text { (not to criticize persons, but } \\
\text { their point of view, to accept } \\
\text { the position of others, despite } \\
\text { the negative attitude towards } \\
\text { them). }\end{array}$ & $\begin{array}{l}\text { - skills to draw an analogy; } \\
\text { - seek to explain the unknown } \\
\text { and obscure; } \\
\text { - see similarities and } \\
\text { differences; } \\
\text { - provide convincing evidence; } \\
\text { - see hidden predictions; } \\
\text { - make reasonable } \\
\text { conclusions; } \\
\text { - make thoughtful, validated } \\
\text { judgments. }\end{array}$ \\
\hline
\end{tabular}

Attempts to introduce elements of philosophy, in most cases logic and psychology, into school education in Ukraine were already observed in the late $19^{\text {th }}$ and first half of the $20^{\text {th }}$ century. However, due to lack of specialists, this subject has been removed from the curriculum. The purpose of the national course "Philosophy for Children" is the formation of certain skillswhich makes it consistent with the American version. The content of such skills has no much difference, although Ukrainian experts largely limit their number and distribute 
in such directions: the skills of critical, tolerant and creative thinking (Lushin, Rzhevskaya, Dannikova, 2003; Sukhomlyns'ka, 2003).

In our opinion, this approach is more appropriate than Lipman's. The teacher does not face a significant field of diverse skills, the formation of which is the basis of the educational process. This specifies the purpose of this activity and allows you to identify which of the skills need additional attention from the teacher.

The works of American researchers in the field of philosophy for children have increasing interest in contemporary Ukraine. Thus, in 1999 an agreement was concluded between Kirovograd State Pedagogical University named after Vladimir Vinnichenko and Montclair State University in the United States of America. Its content is directed to the development of school and university curricula with an emphasis on the formation of critical thinking as an important component of the process of democratization of education and society (Polyarush, 2001).

Since 2018 a new methodology for teaching in schools has been introduced in Ukraine. The technique involves the reduction of theoretical load and the acquisition of knowledge on the technique of "question-answer". Education experts recommend not only the theoretical workload in schools but also the need to provide teachers with the necessary resources. Particularly widespread in Ukraine is the demand for the "Philosophy for Children" methodology in the context of the emergence of NUS (New Ukrainian School). Today, this technique has also been successfully implemented in 80 countries, and its essence is still to teach children to debate, to reason, to find their own arguments and to accept the interlocutor's arguments. According to some scientists, it is necessary to move away from the traditional "cramming" of information in schools, and instead to teach children to include logic and defend their opinion. The experience of the UK has become indicative of the implementation of the "Philosophy for Children" methodology. According to research conducted in 2015 with the participation of three thousand children from 48 schools, it has been found that students who have studied under the "Philosophy for Children" program have the best track record in maths and literature. In addition, students' performance increases (Kontseptsiya novoyi ukrayins'koyi shkoly, 2016).

Nowadays, the implementation of the methodology is still working on individual initiative groups, including the Laboratory "Philosophy for Schoolchildren" at the Philosophy Department of the National Pedagogical Dragomanov University, headed by Nadiya Abramenko, a special research group on philosophy at school at the M.V.Ostrogradsky Poltava Regional Institute of Postgraduate Teacher Education under the direction of Tatiana Bondar, at the Social and Humanitarian Disciplines Department of Dnipro State University of Internal Affairs under the direction of Yuriy Narozhny.With 
Zahrebniuk et al., 2021. The Program "Philosophy for Children":

Positive Experience of the USA

regard to philosophy at the senior school level, one of the possible strategies here could be to isolate the philosophical and humanitarian lyceum as an educational segment between middle and high school. However, projects aimed at establishing the "lyceum" as a separate educational unit are almost absent in Ukraine. Although, there are many institutions with the name "lyceum", more often it is not about general humanitarian education, but specialization in popular areas: economic, legal, media, etc.

Another type is the lyceum at higher education institutions, almost the only example of which is the Ukrainian Humanities Lyceum of Taras Shevchenko National University of Kyiv. There is also a Regional Humanitarian Lyceum for gifted children from the Vinnytsia region at Hrushevsky Bar Humanities and Pedagogical College. This approach is also only a partial solution aimed at preparing for admission to this university, while according to scientists, the lyceum should be "what it is in countries where it has existed for a long time: a separate educational link". As a valid example of a separate institution can be cited Chernivetsky Philosophical and Legal Lyceum, teaching two subjects of philosophical focus which is carried out on the textbooks "History of Philosophy" by Victor Ogneviuk and Irina Utiuzh (Form 10) and "Philosophy" by Vasyl Kremen (Form 11).

On the whole, the question of the introduction of elements of philosophical education at both junior schools and the lyceums is only beginning to be raised without going beyond single initiatives, but it is undoubtedly relevant and needs not only active development but also promotion and dissemination among representatives of the academic philosophical community, educators, representatives of the relevant institutions of state power and the general public that is, work that must precede any systemic change in society (Yasna, 2016).

\section{Conclusions}

Today, the scientific investigation of American researchers (Siegmund, 2019; Siegmund, 2020; Murris, Haynes, 2020; Trickey, Topping, 2004; Bleazby, 2013; Pritchard, 2018) in the field of studying the Philosophy for Children program studying draws a great attention in Ukraine.The conceptual foundations of the American version of Philosophy for Childrenare being introduced into the educational process and are particularly relevant in the context of the development of a new Ukrainian school (Kontseptsiya novoyi ukrayins'koyi shkoly, 2016). The main focus is on the formation of students' critical thinking, the development of the foundations of scientific research, curriculum methodology, human ecology and philosophy for the child. Unfortunately, implementing the foundations of the program has an episodic nature, and therefore it makes it difficult to study the application of this 
approach in the domestic education system and limits the ability to make a qualified assessment.

\section{References}

Abbasi, M., Pirani, Z., Sarmadi, M. R., \& Taghvaee, D. (2017). The Effectiveness of Philosophy Education Program for children on Critical Thinking and its Components in Girl Students. Iranian journal of educational sociology,1(4), 96-103.

Bleazby, J. (2013). Social Reconstruction Learning: Dualism, Dewey and Philosophy in Schools.Routledge: New York and London.

Chetty, D., \& Suissa, J. (2017). 'No Go Areas' - Racism and Discomfort in the Community of Inquiry. The Routledge International Handbook of Philosophy for Children. London and New York: Routledge.

Childhood and Philosophy Special Issue. (2017). Retrieved from https:// www.epublicacoes.uerj.br/index.php/ childhood/issue/view/1498/showToc

Dewey, J. (1967). A Common Faith (117-121). New Haven: Yale UN Press.

Gregory, M. R., Haynes, J., \& Murris, K. (2017). The Routledge International Handbook of Philosophy for Children. London and New York: Routledge.

Gregory, M. R., \& Laverty, M. (Eds) (2018). In Community of Inquiry with Ann Margaret Sharp: Childhood, Philosophy and Education. London: Routledge.

Haynes, J., \& Murris, K. (2017). Intragenerational education: Imagining a postage pedagogy. Journal of Educational Philosophy and Theory, 49 (10), 971-983.

Kizel, A. (2016). Philosophy with Children as aneducational platform for self-determined learning, Cogent Education, 3(1), 15-26.

Kontseptsiya novoyi ukrayins'koyi shkoly. (2016). Retrieved from: https://tribuna.pl.ua/ news/kontseptsiya-novoyi-ukrayinskoyi-shkoli-pivdennokorejsky-professor-proponuyeunikalnu-metodiku-dlya-ditej/

Lipman, M. (1973). Contemporary aesthetics. Boston, MA: Allynand Bacon.

Lipman, M. (1980). Philosophy in the classroom. Philadelphia, PA: Temple University Press.

Lipman, M. (1988). Philosophy goes to school. Philadelphia, PA: Temple University Press.

Lipman, M. (1991). Thinking in education. Cambridge: Cambridge University Press.

Lipman, M. (2003). Thinking in education. New York, NY: Cambridge University Press. DOI: http://dx.doi.org/10.1017/CBO9780511840272

Lipman, M., Sharp, A. M., \& Oscanyan, F. S. (1980). Philosophy inthe classroom. Philadelphia, PA: Temple University Press.

Lipman, M., Sharp, E.M., \& Oskanyan, F. (1979). Filosofskoye issledovaniye.

Lushin, P.V., Rzhevskaya, Z. A., Dannikova,Ye. G., Koltko, N. A., \& Minenko, O. A. (2003). Uchimsya fasilitirovat'. Kirovograd.

Masharova, T.V., Khodyreva, Ye. A. (1998). Uchebnaya deyatel'nost'... Sreda... Razvitiye...: Uchebnoye posobiye. Kirov: Vyatskiy gos. ped. un-t.

Michalik, K. (2018). Uncertainty as challenge and opportunity - teacher and learner perspectives on philosophical discussion in Heike de Boer and Kerstin Michalik.Toronto: Opladen.

Murris, K., \& Haynes, J. (2020). Troubling Authority and Material Bodies: Creating Sympoietic Pedagogies for Working with SOURCES 50 Children and Practitioners. Global Education Review, 7 (2), 24-42. 
Zahrebniuk et al., 2021. The Program "Philosophy for Children":

Positive Experience of the USA

Piaget, Jean. (1933). Children's Philosophies. In C. Murchison (Ed.), A Handbook of Child Psychology (123-156). Worcester, MA: Clark University Press.

Polyarush, O. (2001). Na merydianakh mizhnarodnoyi spivpratsi. Ridna shkola, 2, 42-43.

Pritchard, M. (2018). Philosophy for Children. Retrieved from https://plato.stanford.edu/ archives/win2020/entries/children/

Reed-Sandoval, A. (2018). Can Philosophy for Children Contribute to Decolonization? Precollege Philosophy and Public Practice, 18, 156-159. DOI: 10.5840/p4201811284

Shipman, V. (1983). Evaluation Replication of the Philosophy for Children Program - Final Report. Thinking, 5 (1), 45-57.

Shirman, V. (1982). Evaluation of Philosohy for Children program in Bethlehem. Pennsylvania: Thinking, 4, 37-40.

Siegmund, M. (2019). Philosophy for Children and Teenagers: The best 123 questions: Including many pictures that will encourage the joint thinking process. Retrieved from https://www.amazon.com/Philosophy-Children-Teenagers-bestquestions/dp/3748109997

Siegmund, M. (2020). Philosophy for Children. Grandpa Carl the Owl and his Grandson Nils the Owl, Norderstedt. Retrieved from https:/www.goodreads.com/book/show/ 50642927-philosophy-for-children-grandpa-carl-the-owl-and-his-grandson-nils-the

Sukhomlyns'ka, O.V. (2003). Filosofiya dlya ditey yak pedahohichna problema [Philosophy for children as a pedagogical problem]. Psykholoho-pedahohichni problemy sil's'koyi shkoly. Uman', 6-19.

Trickey, S., \& Topping, K. J. (2004). 'Philosophy for children': a systematic review, Research Papers in Education, 19(3), 365-380. DOI: 10.1080/0267152042000248016

Vaynshteyn, Mark. (2001). Krytychne myslennya yak osnova demokratychnoho navchannya. Ridna shkola. 4,49-51.

Vygotsky, L. S. (1997). Collected works of L. S. Vygotsky. The history of the development of higher mental functions. New York/London: Plenum Press.

Yanovs'kyy, Andzhey. (2001). Shkola hromadyanyna: amerykans'kyy dosvid - nashi potreby. L'viv: Litopys.

Yasna, I. (2016). Filosofiya u shkoli: svitovi vzirtsi ta ukrayins'kyy dosvid. Retrieved from http://ych.org.ua/library/filosofiya-u-shkoli-svitovi 